\title{
Journal of Labor and Society
}

https://doi.org/10.1111/wusa.12421

Published online 23 April 2019

\section{State Violence, Empire and the Figure of the 'Soldier-Victim' in Northern Ireland}

\section{Professor Mark McGovern, Edge Hill University, UK}

\begin{abstract}
This article examines some of the deeper meanings of the denial of accountability in killings perpetrated by British soldiers during the conflict in Northern Ireland, as part of the debate on how to deal with the legacy of the past. It investigates the ways in which such 'soldierperpetrators' are turned, instead, into 'soldier-victims' and asks what this tells us about the political culture that shapes such a response. In part, it will be argued, this is the product of a longer term Manichean distinction, deeply embedded in the history of empire and its wars, between 'civilians' and barbarians'. Here lawfulness, as a mark of 'civility', is identified with the self-image of the (post-) imperial state, contrasted with the unlawful chaos of the barbarian 'Other'. In the context of both the counterinsurgency wars of the late twentieth and early twenty-first century, and amid a presiding mood of 'post-imperial melancholia' and 'heroic failure', the figure of the 'soldier-victim' therefore becomes a means to turn the wrongs of state violence into an ideological potent imaginary of empire, the state (and its agents) as themselves those who have been wronged.
\end{abstract}

\section{Keywords}

Empire, Counterinsurgency, Northern Ireland, State Violence, Denial, Soldier-Victims, Terrorism

\section{Introduction: From Afghanistan to Northern Ireland and Back}

In April 2017 convicted murderer British Army Sergeant Alexander Blackman was freed from jail, having served only three years of a life sentence. In late 2011, in contravention of both international and British law, Blackman (or 'Marine $A$ ' as he was known throughout his trial) shot dead a wounded, captured Taliban fighter in southern Afghanistan (Build-up to Moment Marine Shoots Dead [a] Wounded Taliban Fighter, 2017). Head-cam footage recording the killing inadvertently came to light in 2013 , leading to his trial and conviction. A vociferous public campaign soon followed calling for Blackman's release, spearheaded by the right wing British newspaper the Daily Mail and a raft of leading political, military and other public figures. They succeeded, after his original conviction was reduced to manslaughter.

Blackman had been described as the first British soldier found guilty of murder 'on the battlefield' or on 'active service since the Second World War' (Marine 'A': The Inside Story, 2017; Marine 'A': Criminal or Casualty of War, 2015). This was at best carefully, if not deceptively, worded. There had in fact been a number of British soldiers convicted previously for murders they committed while on duty in the North of Ireland, responsible for a handful of the over 300 people (most civilians from the nationalist/Catholic 
community) directly killed by the British Army during the three decades of conflict (McGovern 2010, p.145). Those soldiers found guilty included several members of the locally recruited Ulster Defence Regiment (UDR), a unit long also the subject of allegations of widespread collusion with loyalist paramilitary groups (Cadwallader, 2013; McGovern, 2019; Pat Finucane Centre, 2014; Ryder, 1991, p.150). In a few (very rare) cases, there were also murder convictions for members of the regular British Army. These included one of four members of the Argyll and Sutherland regiment found guilty (long after the event and only because of a complex chain of circumstances) of playing a role in the brutal 'pitchfork killings' of two Catholic farmers - one a leading local civil rights activist - in Co. Fermanagh in 1972 (Burke, 2018; MacDonald, 2012; McKittrick, Kelters, Feeney and Thornton, 1999, pp.286-7; Newsinger, 2002, pp.128-9). The 'Argylls' had already achieved some notoriety for their imposition of a self-declared 'tribal law' during the final stages of Britain's counterinsurgency campaign in the Crater district of Aden in 1967 (Empire Warriors: Mad Mitch and His Tribal Law, 2004; French, 2011; ). Crafted by the Argyll's commanding officer in Aden, Colonel 'Mad Mitch' Mitchell, 'tribal law' involved a vicious regime of beatings, torture, theft and murder (including the stabbing of Arab youths) intended to suppress the anti-colonial opposition and terrorise the local population. Mitchell would later go on to become a Conservative MP, then military adviser to, first, the racist regime in Rhodesia and - by the 1980s - the anti-Soviet mujahedeen in Afghanistan (Obituary: Lt-Col. 'Mad Mitch' Mitchell, 1996).

Other than that, there were only four instances where soldiers of the regular British Army were convicted for Northern Ireland conflict killings. In each of these cases, a vigorous campaign led by the Daily Mail, right wing political leaders and high-ranking former British Army officers had called, successfully, for their early release. In each case, too, the convicted soldiers not only served less than three years in jail but returned to the ranks of the British Army after being freed. At least one, Private Lee Clegg, who shot dead two unarmed and innocent teenagers in a car in West Belfast in 1990 - and was later decorated for his service to the Parachute Regiment - was part of the British occupying forces in Afghanistan (Hickley and Williams 2007, Rayment 2005).

These cases, stretching back over several decades and up to the present, illustrate the vigour with which certain powerful elements of British society are willing to defend British soldiers even in the extremely rare circumstances where a British court has found them guilty of murder while involved in contemporary counterinsurgency wars. In the process, it will be argued, these state killers become, in the popular imagination, (what will be termed) 'soldier-victims'. Rather than perpetrators of extrajudicial military violence they are cast, instead, as themselves the victims of forces of lawlessness and, if not quite paragons of virtue, then at least the battered outposts of 'civility' in a sea of 'barbarism'. What, then, we might ask, does this tell us about the meaning of the figure of the 'soldier-victim' in British society? What, more broadly, does the figure of the 'soldier-victim' encapsulate and signify? And what impact does this have in seeking justice for crimes committed during the counterinsurgency wars of late empire?

The aim of this article is to address these questions through the prism of the on-going and fractious debate on how to deal with the legacy of the conflict in Northern Ireland. Since the signing of the Good Friday Agreement in 1998, which brought to an end three decades of 
conflict, there has been much progress on many issues as well as many false dawns and backward steps. However, what the North has not seen - twenty years on - is the sort of comprehensive truth and justice mechanism introduced in many post-conflict societies across the world as a means to address a past record of mass human rights abuses (Hayner, 2010; Lawther, Moffett, Jacobs, 2017). This article is also therefore designed to offer some reflections on why this is so, notably in relation to continuing non-accountability for state killings during the conflict. The rhetorical figure of the 'soldier-victim', it is argued, is one that often precludes and prevents such prosecutions. In that sense, Blackman, Clegg and the handful of other British soldiers convicted for state killings, are the exceptions that prove an otherwise more hidden rule.

To examine these issues the article will be divided into six parts. First, it sets out briefly the debate on dealing with the past in the North. Second, it examines evidence of the substantial, sustained and continuing efforts of the British Establishment to ensure that no former British soldier faces prosecution or any legal consequences for wrongdoing committed during the conflict before (third) noting some continuities evident here with a 'culture of impunity' that existed during the conflict itself. The article then examines how such impunity cultures are shaped by a much more deep-seated, longer term (and culturally and politically powerful) identification of British military, and imperial, violence with a conception of 'civility' contrasted to alleged anti-colonial 'barbarism'. This, in turn, it will be argued, reflects the role of a self-justifying idea of inherent lawfulness as part and parcel of modern right-wing formulations of British/English identity and a central trope of what has been termed 'post-imperial melancholia' (Gilroy, 2004). Following Gilroy, the work of leading British conservative philosopher Roger Scruton $(2017,2014,2001)$ will be taken as a paradigm of this condition, illustrating - in exemplary fashion - a conception of English national identity centred on a fiction of an inbuilt affinity, if not innate instinct, for justice. Finally, the (sometimes ambiguous) representations of the 'soldier-victim' evident in contemporary counterinsurgency wars, it will be argued, both reflects and exemplifies this tendency toward post-imperial melancholia, a reconfigured 'cult of heroic failure', and the conceit of intrinsic English - or British - civility (O'Toole, 2018). Rooted firmly in the violence of an imperial past as well as a - deeply troubled and troubling - 'postcolonial' present, the agonistic pairing of martial power and sense of grievance contained in the twinning of the 'soldier-victim', reflects, too, tensions inherent in the on-going denial of empire, even as its counterinsurgency wars are being fought today.

\section{(Not) Dealing with the Past in Northern Ireland}

The question as to whether or not killings by former British soldiers in Northern Ireland should be subject to re-investigation, prosecution and potential conviction forms part of a wider (and deeply contentious) debate about how to deal with the post-Troubles legacy. Between 1968 and 1998, over 3,600 people were killed (and 30,000 injured) as a result of the conflict in and about Northern Ireland (McKittrick, Kelters, Feeney and Thornton, 1999). $60 \%$ of victims were killed by Irish republican paramilitary groups, primarily the Irish Republican Army (IRA). Pro-state loyalist paramilitaries were responsible for just over $30 \%$ of deaths. Roughly $10 \%$ were attributed to state forces - both the British Army and the local police force, the Royal Ulster Constabulary (RUC). There have, in addition, been longstanding allegations of state involvement and collusion in deaths attributed to paramilitaries - particularly (although not exclusively) killings by loyalists (McGovern, 2019, 
2017, 2016; Punch, 2012; Rolston, 2005). At the conflict's end, roughly 2,000 deaths remained unsolved and without anyone having been held responsible. Outstanding allegations of state impunity have remained.

There are many criticisms that can be directed at (what have become known as) postconflict, human rights-based, transitional justice mechanisms as means to deal with such legacy issues. For example, if understood as part of an emancipatory political vision, they can be confounded by many of the pitfalls facing 'left legalism' identified by Wendy Brown (2000). The deployment of rights-derived defences of state actors engaged in spying, covert actions or accused of extrajudicial killing, testifies to the ways in which neutral, universal rights can entrench the subordination of others 'by augmenting the power of the already powerful' (Brown, 2000, p.232). Such truth and justice strategies can, however, provide some means to challenge state narratives of the past and the crimes of the powerful. They represent a potential space within which the unequal struggle of differentially empowered social groups can yet allow those, challenging the interests of the state, to 'narrow the range of permissible lies' (Michael Ignatieff, cited in Hayner, 2010, p.25).

In any case, the North has not had any comprehensive process to deal with the issues left in the conflict's wake. Rather, a 'piecemeal approach' has seen a series of disparate initiatives launched over two decades, including public inquiries, investigations carried out by special 'legacy' police units and a newly created Police Ombudsman's office, and various court cases (Bell, 2002; Lundy, 2008; Lundy, 2012; Lundy and McGovern, 2008; McGovern, 2013). Meeting with varying degrees of success, many of these efforts have been deeply flawed and done little to settle matters. This fragmented landscape has not happened by chance. Crucial have been state attempts to manage truth recovery - particularly in cases of state killings and collusion allegations. Setbacks and ongoing evidence of a culture of state secrecy have been part of a worrying 'roll-back' of human rights provisions established as a cornerstone of the post-Good Friday Agreement settlement (Committee on the Administration of Justice, 2011, 2013, 2015). Innovative, inclusive and encompassing recommendations on a way forward, set out by an officially established Consultative Group on the Past in 2009, were cast aside by the Government almost before they were made public (Consultative Group on the Past, 2009). These would, however, form the basis of a settlement on legacy issues agreed by the British and Irish Governments and main parties of the North as part of a further agreement reached in 2014 (Northern Ireland Office, 2014). Draft legislation was, however, followed by the launch of another public consultation process (Northern Ireland Office, 2018). The purpose of which seems only to seek to delay, defer - if not completely derail and deny - the creation of the legacy process.

\section{Prosecutions, Amnesties and a 'Disproportionate Focus'}

There has been a parallel, rising chorus of rancorous opposition directed against 'legacy' measures, in general, and (in particular) holding British soldiers accountable for past wrongs (Collins, 2018; Matchett, 2018). This has been so, for example, with public debate of potential prosecutions against the members of the Parachute Regiment - an elite unit of the British Army - responsible for killing 14 people during a Civil Rights march in Derry in January 1972 (McCann, Sheils and Hannigan, 1992; Mullan, 1997; Walsh, 2000). In 2010 a second public inquiry into these events, chaired by Lord Saville, overturned the 'whitewash' findings of a first (Saville, 2010; Walsh, 2000: pp.54-112; Widgery, 1972). Reversing the earlier 
exoneration of the soldiers, Saville (2010) found the victims to have been unarmed and innocent and declared the killings 'unjustified and unjustifiable' (McDonald, Bowcott and Mulholland, 2010). A much delayed, halting and long-drawn-out police investigation followed. In early 2019 the decision was taken that of the 16 accused British soldiers only one - 'Soldier F' - would be prosecuted, and for only two of the five killings for which he may have been responsible. The victim's families, vindicated by the decision to prosecute after a decades long campaign, were at the same time left deeply disappointed and dismayed that charges would not be brought against the other accused (never mind laying responsibility at the door of those who had ordered the troops in and commanded them that day) (McCann, 2019). However, true to form, the mere prospect of finding those who carried out the Bloody Sunday killings accountable in the courts had already led to a concerted campaign (by the inevitable right wing elements of the British press and former senior military and political figures) denouncing the investigation as a 'witch hunt' (Mendick, 2018).

The cry of 'witch-hunt' has become ever shriller and broadened out with allegations that state killing cases are being singled out for investigation by a 'Legacy Unit' currently working within the Police Service of Northern Ireland (PSNI) (Moloney, 2018; Newton Dunn and Wilkinson, 2017; Hawkes and Johnson, 2017).' The call has been taken up by the populist press, boosting campaigns and rallies organised by newly created 'veterans' organisations (Devlin, 2018; Ingham, 2018). It is a mix of anti-establishment and nationalistic rhetoric that has also attracted Far Right support, for whom - against the backdrop of the failed campaigns of the 'War on Terror' in Iraq and Afghanistan - veterans issues have been merged with proto-militarism and anti-Muslim racism to further foster a Brexit-inspired rise (Stewart, 2017; Veterans Against Terrorism, 2018).

But opposition to prosecuting British soldiers for past wrongs is not limited to the outer right fringes of British politics. Leading figures and former ministers within the Conservative party have been much to the fore (Fallon, 2018; Willetts, 2018). Their defence of former soldiers has in turn been echoed and endorsed by the British Government. In late 2018, for example, British Prime Minister, Theresa May (HC Deb 12 September 2018) condemned what she described as a 'disproportionate focus' in legacy investigations in Northern Ireland on conflict-killings perpetrated by British soldiers. She had already declared as 'patently unfair [that] terrorists are not being investigated' and that 'the only people being investigated' were former British soldiers or policemen (HC Deb 9 May 2018). These sentiments were echoed by the current Secretary of State for Northern Ireland, Karen Bradley, who condemned a 'disproportionate emphasis on the actions of the military and law-enforcement agencies' (HC Deb 9 May 2018).

The only problem with the 'disproportionate focus' argument is it happens to be untrue. Official PSNI statistics refute such allegations. As of late 2017, it is true that $30 \%$ of current legacy investigations concerned the $10 \%$ of conflict deaths that involved state killings ( $\mathrm{HC}$ Defence Committee, 2017, p.7). This is the foundation of the 'disproportionate' position. However, this leaves aside the number of completed legacy investigations in which state killing cases are significantly under-represented. As of 2017, investigation has been completed of only three state killings - a mere $2 \%$ of the total. $64 \%$ were of deaths attributed to republicans (HC Defence Committee, 2017, p.7). Far from a focus and priority 
given to deaths attributed to the security forces, this suggests the opposite has been true. If so many (though still a minority) of current investigations are into killings by British soldiers and members of the Royal Ulster Constabulary (RUC) that is largely because they are the only ones left. Likewise, five times more legacy prosecutions had been pursued against alleged paramilitary members than against British soldiers (Kearney, 2017; Young, 2017). 'These figures speak for themselves', declared the Chief Constable of the PSNI (cited in Kearney, 2018). The officially appointed Northern Victims' Commissioner (cited in Walker, 2018) similarly stated that the Prime Minister's comments were 'completely in contravention of the facts' and there is 'no evidence that there has been any systematic or unsystematic targeting of state forces'.

However, British policymakers have not allowed such facts to impact on their views or hinder their work. The false depiction of a 'disproportionate focus' on investigating state killings has also had worrying policy implications. In 2017 a House of Commons report (2017, p.16) proposed the introduction of a statute of limitations - essentially an amnesty - to cover 'all Troubles-related incidents' in which 'former members of the Armed Forces' were involved. "ii The current Defence Minister is an avowed advocate of such a move and has been working on legislating to that end (Buckley, 2018a, 2018b). As far as the British Government is concerned the only problem at present - and one which equally exercises the ire of the right-wing press - is how to put such an amnesty in place without having to do the same for former members of the IRA (Little, 2018). A 'statute of limitations' for British soldiers accused of extrajudicial killings or war crimes - in Afghanistan and Iraq as well as Northern Ireland - now seems to be very much on its way. Cutting across due process, there have also been suggestions that no prosecutions of former British soldiers would proceed unless expressly approved by the Attorney General - something the record of the past suggests they would very likely be unwilling to do. Indeed, in the wake of the decision to prosecute 'Soldier $\mathrm{F}^{\prime}$ in the case of Bloody Sunday, officials expressed regret that such a statute had not already been put in place. This followed profoundly troubling (if not illegal) comments from several senior Conservative figures in the lead up to the 'Soldier $F^{\prime}$ announcement that no such prosecutions should happen. The Northern Ireland Secretary Karen Bradley (HC Deb 6 March 2019), outrageously, went so far as to tell the House of Commons that all the killings perpetrated by 'the military and police' during the conflict were 'not crimes' but were people 'fulfilling their duties in a dignified and appropriate way'.

\section{Cultures of Impunity}

Contrary to current claims of a witch-hunt aimed at British soldiers for past crimes - the killers of Bloody Sunday chief among them - the record also shows there was, if anything, a long term de facto immunity and a priori amnesty for military wrongdoing during the conflict itself (Lundy, 2012). Throughout the 'Troubles', public adherence to the principle that security force personnel were subject to the rule of law was paralleled by an unspoken culture of (at the very least) official tolerance. For political reasons, from the outset of the conflict, the formal indemnification of British soldiers for serious wrongdoing on duty - or attempts to 'legalise lawlessness' - was viewed as a problem (Attorney General Basil Kelly, in Committee on Interrogation Procedures, 1972). Such a move would have made apparent the suspension of liberal democratic norms that were, in practice, part and parcel of the counterinsurgency campaign. Likewise it would have immediately drawn unwelcome analogies to other late colonial wars. So, informally (but no less powerfully for that), 
assurances were given by, for example, the Attorney General for Northern Ireland in 1971, that he would do 'all within his power to protect the security forces from criminal proceedings' ('Memo from Head of C2 at HQNI and the Attorney General, 6 December 1971, AG 1971, pp.2-3').

A range of ways and means were therefore put in place, adapting and subverting legal due process, to all but ensure military immunity from prosecution whilst maintaining the façade of 'constitutional propriety' (Ignatieff, 2004, p.72; McGovern, 2010, p.139). These included, for example, (in the early days of the conflict) making sure that the investigation of state killings was conducted by military rather than civil authorities; fundamentally changing the nature of the court system and drastically expanding the 'reasonable force' grounds on which state lethal force was justified (Jennings, 1990; Lundy, 2012; Ní Aoláin, 2000; Urban, 1992, 1997; Walsh, 2000). A phalanx of Army legal experts was readily available to provide advice so that soldiers' narratives of events could explain away their actions as 'selfdefence'. As a civil court found in 2011, denouncing one such British soldier's testimony, some victims seemed to develop a surprising (indeed, life-imperilling) tendency - contrary to 'reason and the instinct for self-preservation' - to reach for weapons they did not actually have (High Court of Justice of NI, 2011, p.5). During the conflict, however, such narratives were almost always accepted by the courts. Legal and legislative changes could combine, too, with an informal culture of institutionalized permissiveness that had all the more purchase within the 'closed system' of the 'total institution' of the military (Goffman, 1961).

Much here points to a culture of impunity that goes far beyond the idea that state killings were merely the result of 'indiscipline' or the actions of individual soldiers that then needed to be covered up in the aftermath. The calculated and co-ordinated steps to ensure British soldiers would not end up in court cannot be viewed in isolation from wider patterns of state practice that suggest otherwise. These included routine calls from senior military figures (often on the eve of major operations), for their soldiers to be 'uncompromising and determined' in their dealing with local people (Briefing notes for officers and soldiers: Operation Motorman, 1972). One mused (just prior to the Bloody Sunday shootings) whether the 'minimum force necessary' to restore order might be to 'shoot selected ringleaders' of rioters (Major General Robert Ford, cited in McCann, 2019). Indeed, the draconian steps taken sometimes paled by comparison with the 'doomsday scenarios' given serious consideration by the British political and military hierarchy. One plan explored in depth in mid-1971 would have seen the introduction of martial law, the full-scale deployment 'on a war-like footing [of] overwhelming military force' to achieve the 'saturation' and 'swamping' of Catholic working class area and the creation of 'free-fire zones' (within which it would be 'essential for a soldier to be able to open fire without fear of legal penalty in certain circumstances') (cited in Charters, 2017, p.164; Sanders, 2013, p.477). It was an option kept on the table for some time afterwards. In light of that, the numerous state killings and widespread violence that followed the introduction of internment could be viewed by military planners as a more benign outcome than might otherwise have been the case - less a product of condemnable excess than condonable restraint.

Nor can efforts to exonerate individual soldiers be divorced from the whitewash work done by various inquiries and tribunals, or from the darker dimensions of the North's covert 'dirty war' - from the use of 'counter-gangs' like the Military Reaction Force in the early 1970s, the 
deployment of covert counterinsurgency units (such as the SAS) in 'set-piece' shoot-to-kill ambushes in the 1980s, and widespread collusion, institutional in scale, scope and nature, evident through to the 1990s (Britain's Secret Terror Force, 2013; Hearty, 2014; McGovern, 2019; Murray, 1990).

While there were some differences, these patterns of state practice also find echoes in other, earlier, post-1945 British military colonial campaigns in Palestine, Malaya, Kenya, Cyprus and Aden (Drohan, 2017; Newsinger, 2002). Creating spaces of legal indeterminacy, categories of communities subject to different regimes of punishment, and the partial implementation of law, were all legalistic strategies deployed to mask the violence of empire in an emerging era of international human rights (Khalili, 2013, p.81). Fighting 'liberal wars' in colonial and 'neo-imperial' settings sees a counterinsurgency violence forged by a doctrine of necessity fused with, and hidden by, a claim to liberal legal principles and the language of a 'civilising mission' (Khalili, 2013, p.4). Within British counterinsurgency theory, the outcome were the myths of adherence to a supposedly benign 'hearts and minds' approach and 'minimum force' doctrine, that combined with the (often wholesale, sometimes maximalist) violence of its interest - rather than moral - driven practice (McGovern, 2015, 2019, Owens, 2015).

Of course, such cultures of impunity have an institutional, practical and instrumental logic. (Mostly) young men sent by the state to kill and maim may be less inclined to do so if potentially liable to criminal culpability at some unknown later date. That is something of which military hierarchies are all too aware. It forms a less openly spoken corollary to the 'informal understanding of mutual obligations' commonly known today as the 'military covenant'. But there is much more here besides. In order to see more clearly the ways in which the figure of the 'soldier-victim' may encapsulate some of the contradictions of the violence and rhetoric of the 'liberal wars' of empire, it may be worth taking a few further steps back.

\section{Civilians and Barbarians, Colonialism and Law}

UDR members and the 'pitchfork' killer aside, the dishonour of being the first British soldier convicted of murder during modern conflict belongs to Private lan Thwain. He shot Thomas 'Kidso' Reilly in the back on a hot August evening in west Belfast in 1983 (McKittrick, Kelters, Feeney and Thornton, 1999, pp.948-949). Thwain told the court he feared Reilly - who had just been stopped and searched by a British Army patrol - might have had a gun hidden under his shirt when he was not actually wearing one. So incredulous was his evidence that, highly unusually, the judge simply did not believe him and said the defence case had been 'manufactured' (Mr Justice Higgins, cited in Jennings, 1990, p.122). Convicted to life imprisonment, Thwain was nevertheless released into 'military custody' only two years later, following a press campaign to free him. He immediately returned to active service with his regiment.

In the same year Ian Thwain murdered 'Kidso' Reilly, Seamus Deane (1985) argued the conflict in the North, indeed much of the history of relations between the two islands, exemplified in the 1981 republican hunger strike, was all too often ideologically framed as a binary struggle between 'civilians' and 'barbarians'. iii It was a distinction, said Deane, with a long history. The essential paradox of 'European theories of freedom' from John Locke 
onward, Deane $(1985$, p.33) argued, lay in the contradiction that law compels men to be free' forming the basis of a difference drawn between the civilised and the barbaric, where 'those who live under the law are civilians; those who lie beyond it are barbarians'. It was a logic, said Deane, already evident before being articulated in philosophical terms by Locke, that had done much to shape English expansionist and early colonial policy in Ireland from the late sixteenth century onward.

Likewise, for Ellen Wood (2003, pp.81-2, pp.96-100), the epoch-shaping justifications for the early seventeenth century Plantation of Ulster prefigured Locke's later extension of the concept of terra nullis and ushered in the era of capitalist empire and the violent expropriation of property on the permissive foundation of a 'specifically English sense [of] value'. The distinction of barbarians, devoid of law, and settler rights dressed up in claims of 'natural law', allowed such colonial appropriation without the consent of any local sovereign' precisely because indigenous custom and practice was relegated to a Hobbesian chaos of Law's absence (Wood, 2003, p.97). In this sense, Ireland became a 'legal seedbed for the expansion of the British empire' (McAuslan, 2015, p.201).

Certainly the writings of early propagandists (and practitioners) of English colonialism in Ireland - such as the poet Edmund Spenser and Sir John Davies - provided exemplary models for later justifications of colonial expansion, appropriation and dispossession, not least in the Americas (Pawlisch, 2010; Orr, 2003. For Spenser, a policy of war, of 'extra-legal slaughter' and 'military and judicial violence', was required as the only 'agent of civilization' by which the 'barbarous' the Irish might be 'compelled to be free' (Orr, 2003, p.401. See also Canny, 1973, p.581).. On the other hand, Davies - Attorney General in Ireland at the time of the Ulster Plantation - viewed English Common Law as a key instrument of colonisation' and a means to fundamentally recast social property relations. His was a logic of 'legal imperialism' and programme of 'practical colonialism' that was an important template for the future (Pawlisch, 2010).

Whatever separated the views of Spenser and Davies, however, more united them. Both saw colonial 'pacification' as the primary goal. Both also understood that the power of Law relied on the capacity for force that lay behind it. Both also, crucially, saw English Common Law as what distinguished the boundary between the civility of the coloniser and barbarity of the colonised. For both, it was the possession of English Common Law, above all else, that defined civility, made the English who they were, and allowed for colonial 'rights' to always take precedence over the 'lewd customs' of the native.

This, too, has proven to be a foundational aspect of 'legal imperialism'. Here also, in property-based, embryonic form, was a 'standard of civilization' that would develop over time as an international legal mechanism by which 'people or nations have historically been... barred from the international society of states' (Bowden 2009, p.103). Forming part of a 'universalising Western imperial project', the 'principle of a legal standard of civilization' not only facilitated imperial expansion by helping to 'subordinate and extinguish alien cultures' and enshrine European norms, values and interests in the body of international law, it also helped make the very idea of Law and lawfulness synonymous with the sense of collective self of emerging popular identities of colonialism and empire (Bowden 2009, p.128; Anghie 1996, p.333. See also Anghie, 2007). 
For Seamus Deane (1985, p.39, p.42) a 'putative division' between barbarism and civilization would continue to act as a 'blighted distinction', governing our responses, shaping the language of politics and setting a limit to our imagination of and about the North of Ireland into our own time. On the one hand, Irish barbarism has been imagined as a 'chaos of arbitrary wills' and a social order dominated by 'local kinship loyalties and sentiments' (Deane, 1985, p.39). On the other, English civilization as a 'system of law' in which the tradition of Common Law has long been imagined as the historical foundation of a readily assumed affinity between Englishness, civility and justice. It is a distinction we may continue to see echoed more widely, and more destructively, in the language of 'failed states', 'liberal peace' and peoples 'unfit for liberty' elsewhere.

\section{Englishness, Post-Imperial Melancholia and 'Law's Enchantment'}

Celebrations of 'the law' and lawfulness as a 'peculiarity of the English' are not something consigned to a long-gone past (Thompson 1965). They can, also take on a range of distinctly different, at times radical, forms. One need think only of George Orwell's 1941 hymn to 'socialism and the English genius' in which his efforts to rouse a spirit of left popular patriotism in support of the war are centred on extolling the virtues of English national character (Orwell, 1982). For Orwell, at the core of what he calls the 'English mystique' and an 'all-important English trait', is a respect for 'legality' and a 'belief in "the law"' as something that should be 'incorruptible' and 'impartially administered'. Similarly the eminent historian E.P. Thompson (1975, p.265-6) argued that a centuries-old tradition of English law, enshrining and entwined with 'customary practice', able to defend citizens from 'power's all-intrusive claims', represents a 'cultural achievement of universal significance [and] an unqualified human good'. Whether the fruits of such English liberty were ever extended to imperial subjects is, however, another question again - and one which undoubtedly also greatly troubled both Orwell and Thompson.

However, it is the identification of 'the law' and lawfulness with Englishness (sometimes, Britishness) as a distinct strain within modern British conservative thought - and its even further right counterparts - that is the primary focus here. It is from such quarters and ideological standpoint that the vociferous defence of accused British soldiers become 'soldier-victims' is most often heard. This is also an outlook in which a particular, if not unique, English gift for law-making and law-abiding forms part of a more pervasive, powerful and pernicious cast of mind, that has helped shape the rhetoric of a more recent, surging - if often inchoate - pro-Brexit, 'take-back-control' populist English nationalist project (O'Toole, 2016, 2018). In this perspective, it will be argued, 'the law' is transmogrified (somewhat ironically, given a supposed English predilection for all things empirical) into a sort of transcendent, mystified force, that is, in turn, regarded as the product - and property - of a particular culture and tradition, as well as an all-too-often racialized idea of civilization. This, too, has both a much longer lineage and contemporary face.

Such contemporary Right narratives of English nationalism can be understood as a product of what Paul Gilroy (2004) calls 'post-imperial melancholia'. Standing in binary opposition to the promise of a 'convivial culture' - built on the boisterous, productive everyday interactions of a multiculturalism moving 'beyond race' - 'post-imperial melancholia' has 
framed 'race talk' in Britain for decades (Gilroy, 2004, p.95). For Gilroy, this 'syndrome', 'pathological' in nature, combines a culturally immersive yearning for a falsely drawn vision of the imperial past with an equally imaginary sense of 'imperilled Englishness' (Gilroy, 2004, p.98, p.130). In turn, this provides a means to both offset the troubling recognition of empire's crimes and replace it with the 'exceptionally powerful feelings of comfort and compensation produced by the prospect of even the partial restoration of the country's long-vanished homogeneity' (Gilroy, 2004, p.95). The suppression of knowledge of imperial violence required comes at 'considerable moral and psychological cost' and the 'guilt-ridden loathing and depression' that follows is expressed instead through 'Britain's xenophobic responses to the strangers who have intruded upon it more recently' (Gilroy, 2004, p.98, p.102). Ultimately, then, the loss of empire and the uncertainty left in its wake, produces this sinuous, evocative, distorting and destructive state of 'melancholia'; understood as the 'depressed reaction following a radical loss of moral legitimacy' (Gilroy, 2004, p.107).

As a powerful social, political and cultural force in contemporary British social life, postimperial melancholia can only function, then, through a collective amnesia of empire's violence. This is paralleled by a self-drawn portrait of Britishness and Englishness as synonymous with the law and lawfulness. In his dissection of 'post-imperial melancholia' Gilroy (2004, p.125) identifies England: An Elegy, written by the leading British philosopher and Conservative guru Roger Scruton, as a more than usually coherent and serious expression of the condition. As the title suggests, England: An Elegy (2001, pp.44-46) is a nostalgia-drenched study of what Scruton sees as the 'real causes' of 'Englishness'; something he understands as a 'distinct human type', that is fast disappearing, if not already lost. Shaped by landscape and church this 'English character', Scruton (2001, p.56) argues, was also definitively and 'profoundly influenced by the Common Law'. Rooted in 'the ancient prerogatives of the people', for Scruton (2001, pp.53-56), English Common Law stands not only as an 'objective reality', but as a sacred, spiritual force, 'a version of the Holy Ghost - always present, always vigilant, always personal, always benign'. The result, he claims (Scruton 2001, p.53) is that the English 'perhaps more than any people in the modern world... [are] sensitive to the distinction between power and authority'. This finds expression in an intrinsic English 'instinct for justice and fair play'; a claim, Scruton insists (2001, p.55), that has only latterly become controversial and hard to establish, if not 'effectively destroyed', by what he denounces as a 'one-sided anti-colonial literature which has effectively demonised empire'.

A sense of justice thus naturalised as an innate quality, generates in turn an inherent capacity for legal wisdom, celebrating 'the ordinary individual in his attempt to live by the law' (Scruton 2001, p.117). Tellingly Scruton saw such 'legal wisdom' personified in the figure of Lord Denning - described by former British Prime Minister Margaret Thatcher as 'probably the greatest English judge of modern times' (cited in Burrell, 1999). As well as once writing of Black jury members as 'an alien presence in our midst', when faced with overwhelming evidence of British policemen being guilty of perjury, violence and forcing confessions in the appeal of the 'Birmingham Six', Denning (cited in Clifford, 2016) could see only 'an appalling vista' that 'every sensible person in the land' could simply not find true (Sedley, 1999. The Six went on to serve another decade in prison, before finally having their sentences quashed on those vey grounds. No convictions of the policemen involved followed (Hill, 1995; Mullin, 1990). 
Scruton further mystifies the identification of Englishness and the Law through an 'ethical idea' he names 'enchantment'. Characterised as capturing 'England in a nutshell... as a 'blessed, enchanted place', 'enchantment', Scruton (2001, pp.210-2) argues, connects the land and legitimate order, where 'justice, law and the mystical authority of kingship reign undisturbed'. Tellingly again, if 'exemplified in the work of Shakespeare - the 'most English' as well as the 'greatest of English writers', the cultural expression of 'enchantment' can be found in a longer tradition established by earlier poets, the colonial adventurer and apologist Edmond Spenser chief among them. Further wrapped up in this mystified, selfimagined Englishness is Common Law itself, cast as an 'enchantment that lay over the land' (Scruton 2001, p.129); a magical condition, paradoxically again, founded in an empirical creativity where law divines an already existing natural justice.

So too, as enchanting law became part and parcel of imperial order, the inherent fairness of its judgements', Scruton contends, 'made law England's largest invisible export' (Scruton 2001, p.129). Much, of course, contests this beatified portrait of English law's benign transplantation. In but one example - as Shashi Tharoor (2017, pp.90-91) has recently argued - while India's penal code is regularly given "pride of place" in celebrations of empire's legacy, justice under British rule was in fact "highly attentive to the skin colour of the defendant" and there was a pronounced "disinclination" on the part of British judges "to find any Englishman guilty of murdering an Indian". Attempts by rare, non-racist administrators to act otherwise invariably resulted in populist expatriate outcry, their swift removal and an equally rapid return to a far from egalitarian or colour-blind status quo.

Yet, it is this myth of an innate, naturalised proclivity for justice, of an inherent decency in the face of the indecent, that is so central to the problems we face and reflective of what is at stake, in the figure of the accused British soldier. When pulp thriller author and right wing campaigner Frederick Forsyth (2017) cast the case of Marine ' $A$ ' as a 'shambles that shames us all', and the campaign to free him as one that started 'with a gut feeling... just a very British sense that something had happened that was not fair', in rampant, populist form he taps into a rich well of this sublimated sense of a collective self. It is equally reflected in populist responses to the potential prosecution of British soldiers for killings in the North. It is this much broader cultural assault, a charge of 'barbarism', of not submitting to the freedom of the law, which is therefore contested and then refused, by transforming the accused British soldier into the cipher of the 'soldier-victim'.

\section{'Wholesome Militarism' and 'Heroic Failure': Empire, Pollution and the Figure of the Soldier-Victim}

Scruton's conception of English 'enchantment', notes Paul Gilroy (2004, pp.125-126), stands in for much else. Anti-immigrant sentiment becomes aestheticized as 'fatal disenchantment'; the result, then, not of racism but the 'loss of enchantment which made home a place of safety and consolation' (Scruton 2001, p.7-8). As Gilroy (2004, pp.95-96, pp.107-108) also argues, the distinction of the 'savage and the civilised' is likewise a key element of the condition of post-imperial melancholia and (undermining the necessary narcissism of empire), 'the loss of the fantasy of omnipotence'. The savage/civilized dualism, constantly revisited, provides an assurance that 'we are still good while our uncivilized enemies are irredeemably evil' (Gilroy 2004, pp.95-96). If on the one hand the figure of the 
immigrant has come to stand for 'all the ambiguities of the Empire's painful and shameful... history' it is opposed by no 'single iconic human cipher' but rather that, in darkest times, Britain would be 'rescued by the sacrifice of its colonial soldiery' (Gilroy 2004, pp.109-110). In Britain's celebration of this 'wholesome militarism' the 'warm glow' of lost homogeneity is regained, if only temporarily, and in the imagination - 'enchantment', we might say, precariously re-cast (Gilroy 2004, pp.95-96).

This points to the way in which the figure of the 'imperial solider', as a cultural construct, can and has been invested with a range of meanings capable of reflecting, reinforcing or unsettling pervasive, hegemonic political projects (Cooper and Hurcombe, 2009; Dawson, 1994; Mosse, 1990; Wittman, 2011). More broadly, the figure of the soldier has often functioned as a wellspring, a 'point of origin of a myth of community... instrumentalised as the bearer of the nation's values and the embodiment of its perceived qualities' (Cooper and Hurcombe 2009, p.103). Likewise, the long-standing iconography of the solider-hero has been a 'potent configuration' of populist imperial populism and hyper-masculine virtues (Dawson 1994, p.1). Casting the 'imperial solider' in heroic mode allowed for the celebration of martial prowess and a 'warrior ethos' as a key element of the self-identity of British and other European colonial powers. It was a potent trope, if one long at odds with the savage realities of the 'butcher and bolt' campaigns of empire and the far greater burden of loss and sacrifice placed on the colonised by overwhelming western military technological superiority.

The idealised self-image of the imperial soldier became harder to sustain in the public glare that increasingly accompanied the late colonial counterinsurgency conflicts of the post-1945 period - whether in Palestine, Kenya, Aden or Vietnam; one reason why wilful amnesia surrounds so many of these wars. In turn, the more recent, often unpopular and 'messy' 'War on Terror' counterinsurgency campaigns fought in Iraq and Afghanistan have seen greater complexities and ambiguities evident in the cultural meaning of the figure of the soldier (McCartney, 2011; McGarry and Ferguson, 2012; McGarry and Walklate, 2011). Loss, retreat and failure has been played out in the image of the 'soldier-hero' (still very far from absent) being joined by those of the soldier as 'victim' and 'perpetrator'. In terms of the figure of the 'victim', for example, a complex of defeat and populist patriotism is evidenced in the image of the 'home for heroes' veteran of Iraq and Afghanistan, betrayed by political masters and the 'top brass' as an ill-equipped, poor relative, reduced to the dread status of 'sepoy' to his over-fed, uber-armed American cousin (Gilroy 2004, p.101).

Yet in most such analyses of these representations, each of the figures - the soldier as 'hero', 'victim' or 'villain' - still tend to be contrasted with each other. However, the figure of the 'soldier-victim' with which this study is concerned involves and invokes a darker and more interwoven matrix of cultural meanings. Here, victimhood is simultaneously and intimately tied up with, rather than distinct from, the figure of the 'perpetrator'. Reimagined as wrongly accused, the 'soldier-perpetrator' is transformed, first, into victim through imagined suffering - then hero, through imagined stoicism.

In the process the efficacy of the soldier as central to the self-imagination of a virtuous national identity is revealed to be a sword that can cut both ways. In the figure of the accused soldier, it is the mythologised national self-imagination of lawful civility contrasted 
with the violent barbarity of the colonial 'other' which is ultimately called into question. Yet, as Gilroy (2004, p.103) again suggests, an abiding feature of post-imperial nostalgia is a tendency to allocate a 'large measure of [the] blame' for empire's crimes to empire's victims while, conversely, Britain (and in this case it's soldiers) are placed in the 'honoured place of suffering'.

This is a mood and mode of thought more widespread now than ever. For Fintan O'Toole (20018, p.xvii, p.66) a wave of anti-EU, Brexit-inspiring sentiment has seen a profound reimagination of the 'structures of feeling' underpinning English national identity and the 'strange legacy of colonialism' evident in the mythic narratives of 'the cult of heroic failure'. This celebration of empire's disasters (from the Charge of the Light Brigade to Dunkirk via Scott of the Antarctic) was always an 'exercise in transference' (O'Toole, 20018, p.72). The imagined stoicism and personal virtue that 'heroic failure' enshrined were long a means to sublimate imperial violence and 'fill the yawning gap' between a 'self-image of liberty and civility' and the destructive realities of domination. What has changed, however, is that now, the myth of stoic endurance has been replaced by what O'Toole (20018) describes as a 'self-pitying' turn.

Here, the anxiety induced by the loss of power sees the rise of 'zombie imperialism' - where a sense of injustice is combined with that of superiority in a 'perfect circle of self-pity and self-love' (O'Toole, 2018, p.xvii, p.44, p.55). What is now envisaged is a 'strange sense of imaginary oppression' alongside a perverse 'appropriation of anti-colonial resistance'. In this 'dystopian fantasy', with the 'coloniser [now] imagining itself as the colonized', the 'great holding back' of stoic understatement is replaced instead by a hysterical 'great letting go' (O'Toole, 2018, p.34, p.77). A rhetoric of migrant 'invasion' and 'colonization' by stealth sees the empire make delusional claim to the real loss and dispossession of 'subject peoples' (O'Toole, 2018, p.91). 'This may be the last stage of imperialism', O'Toole (2018, p.21) concludes, 'having appropriated everything else from the colonies, the dead empire appropriates the pain of those it has oppressed'. Here empire turns itself into piteous victim amid the 'fag end' imperial 'Anglospheric adventures' in Iraq and Afghanistan even as it simultaneously yearns, forlornly, for a post-EU rebirth of 'Empire 2.0' (O'Toole, 2018, p.84). This is an Atlanticist, Anglo-centric myth dream which, inevitably, for Roger Scruton (2017, p.113), is founded on the uniqueness of common law as the (definitively un-continental) 'roots of British freedom'. It is in this context of 'post-imperial melancholia' and 'self-pity', that the figure of the soldier-hero is then matched, if not eclipsed, by that of the soldiervictim; a figure that comes to stand for the wider sense of victimhood, grafted with superiority, in this re-configured memory of empire and re-imagination of Englishness.

The trick, as it were, remains 'staying clean'; or rather of appearing to and, if having fallen, of being returned to a redeemed state of grace. For Scruton (2001, p.50) England's genius for producing 'intrepid adventurers and explorers' (let's say, rather, imperialists) was paradoxically - a fear of contamination, rooted in the legacy of puritanism. However mythic, in the long history of empire, inoculated resistance to cultural interchange proved in practice, an imagined ability to remain 'uncontaminated', immunised by Englishness, of seeing people 'among whom they wandered' as 'essentially other' supposedly meant the administrators and soldiers of empire could 'go anywhere, encounter anyone, suffer anything and emerge unpolluted' (Scruton 2001, p.50. See also Colley, 2002, p.360). And so 
we return again, now cast in terms of cleanliness and dirt, of pollution and inoculation, to the 'blighting distinction' of 'civilians' and 'barbarians'. Just as, for Seamus Deane (1985, p.42), though drawing diametrically opposed conclusions, the horror of the 1981 republican hunger strike played out all too vividly an agreed contrast of mutual imagination; 'vulnerable, Irish squalor' and the 'filthy nakedness' of the prisoner on the one hand, and the 'impervious, impersonal English decontamination' of the disinfecting jailers' on the other.

The 'evacuation from consciousness of postcolonial conflicts', says Gilroy (2004, p.97), parallels the affective power of the imagination of 'wholesome militarism'. At the same time the figure of the 'professional' British soldier, untainted in intent and purpose, a cipher or moral cleanliness in a dirty world, must also be redeemed from the inevitable 'pollution' brought with the stark realities of war and suffering, and not least the 'grey zone' of counterinsurgency warfare. This sheen of cleanliness and order, helping to offset any troubling recognition of culpability and wrong-doing, is in part achieved by lionising the normative culture of the military 'professional'. Even more so, in the figure of the British soldier-victim is played out the comforting myth that 'we' remain clean even when our hands are made dirty by what we are 'required' to do. It means the oft-repeated apologia from official wrongdoing, of the 'bad apple that spoils the barrel', must be adapted further. In the case of the 'solider-victim', the 'apple' has not made itself rotten, still less, of course, does fault lie with the 'barrel' of the military institution. Rather, it is the malignant, infecting unclean context into which both have been placed that has soured the fruit.

\section{Conclusion: 'Decades of Deceit' and the Solider-Victim Figure}

In November 2018, some 47 years after the event, a fresh inquest finally opened in Belfast into what has become known as the Ballymurphy Massacre (Carroll, 2018). The inquest is charged with investigating the killing of 10 people in Ballymurphy, a Catholic working class area of West Belfast, over a period of 36 hours, from 9-11 August, 1971, at the hands of members of the Parachute Regiment (De Baróid, 1989, pp.112-24; McKittrick, Kelters, Feeney and Thornton, 1999, pp.82-90; The Ballymurphy Precedent, 2018). ${ }^{\text {iv }}$ The victims included a 44-year-old father of thirteen children, a 45-year-old mother of eight and a Catholic priest shot in the back while waving a white handkerchief and giving the last rites to a badly wounded man. ${ }^{\vee}$ Eyewitnesses say they saw a Paratrooper deliver a coup de grâce shot to the back of the head of one of the dead as he lay wounded on the ground. ${ }^{\text {vi }}$ Another was shot 14 times. An eleventh victim, a local housing and youth community worker, who had come from England to work in the area, died from a heart attack after being subjected to a mock execution by a patrol of Paratroopers. vii There was no inquiry into the Ballymurphy massacre and no solider has ever been prosecuted or convicted for these killings.

Less than six months after the massacre in Ballymurphy, soldiers of the self-same regiment would be responsible for the Bloody Sunday killings in Derry. If the story of Bloody Sunday would resonate around the world, the 'Ballymurphy precedent' became the 'forgotten massacre' (Bielenberg, 2018). Some of those directly involved in the Bloody Sunday killings had earlier taken part in the shootings in Ballymurphy. Despite the coruscating criticisms of the British Army made in 2010 Bloody Sunday Report, Lord Saville failed to lay blame at the feet of senior military and political leaders. In part, he said, this was because he was unable 
to 'express a view' as to whether a 'culture of impunity' existed in the military given the lack of investigations and prosecutions in earlier state killings (Saville, 2010, p.92). In other words, only by looking at events like the Ballymurphy massacre, could the full picture have been revealed. That, Saville had decided, was beyond his remit.

Yet, as with Bloody Sunday and other state killing cases in the North, efforts since to investigate British soldier's actions in Ballymurphy have immediately been met with the inevitable cries of 'witch hunt' (Brown and Williams, 2015). Once again the 'soldierperpetrators' of Ballymurphy have begun to be turned into 'soldier-victims'. In turn, memory of the Ballymurphy massacre has become the latest contested terrain on which the dualism of lawfulness and chaos, of civility and barbarity, is being played out. In this wider cultural and political sense what is at stake goes far beyond the fate of the 'soliderperpetrators' turned 'victims' alone. Denying a history of wrongful violence, expunging such memories from the official record of the past, remains the work of a culture ensnared by post-imperial melancholia, and intent on preserving the 'honoured place of suffering' for itself. The perverse reversal of roles of perpetrator and victim likewise echoes the shapeshifting phantasm of 'empire' turned 'colony', of 'invasion' and 'resistance', in the anti-EU reactionary and violent dreaming of an 'oppressed Englishness' today. And as long as such distracting, disturbing delusions remain, and feed into wider post-imperial fantasies of the blighting distinction of the lawful civilian and lawless barbarian, the victims of illicit British Army violence, in Northern Ireland, Iraq, Afghanistan or elsewhere, will remain officially unmourned, 'un-grievable lives' (Butler, 2010).

\section{References}

Anghie, A. (2007). Imperialism, Sovereignty and the Making of International Law.

Cambridge: Cambridge University Press.

Anghie, A. (1996). Francisco de Vitoria and the Colonial Origins of International La'. Social and Legal Studies, 5, pp.321-336. doi:10.1177/096466399600500303.

Bell, C. (2002). Dealing with the past in Northern Ireland. Fordham International Law Journal, 26, 1095-1147.

Bielenberg, K. (2018). Seeking justice for Belfast's forgotten massacre. Irish News, 18 November. Retrieved from https://www.independent.ie/irish-news/seeking-justice-forbelfasts-forgotten-massacre-37533040.html.

Karen Bradley MP, Secretary of State for Northern Ireland, 'Stormont House Agreement: Legacy Debate', Hansard, HC Deb, 6 March 2019, vol. 655, cc.945. Retrieved from https://hansard.parliament.uk/commons/2019-03-06/debates/63BF8914-DC20-419C-A2F0D91521845987/StormontHouseAgreementLegacy.

Karen Bradley MP, Secretary of State for Northern Ireland ,'Northern Ireland Debate', Hansard, HC Deb, 9 May 2018, vol. 640, cc.661. Retrieved from https://hansard.parliament.uk/Commons/2018-05-09/debates/96F401BF-CC2F-4A7A-A2081199480A6B9F/OralAnswersToQuestions.

'Briefing notes for officers and soldiers: Operation Motorman: Appendix 1 to Annex $B$ to Operation Instruction 2/72, dated July 1972'

Bowden, B. (2009). The Empire of Civilization: The Evolution of an Imperial Idea. Chicago: University of Chicago Press.

Britain's Secret Terror Force. (2013). [Documentary]. BBC Panorama. 
Brown, L. and Williams, D. (2015). Witch-hunt: ex-Paras verdict as Bloody Sunday troops face new quiz over civilian deaths during riots before Londonderry violence. Daily Mail, 31 December. Retrieved from https://www.dailymail.co.uk/news/article-3379622/Witch-huntEx-Para-s-verdict-Bloody-Sunday-troops-face-new-quiz-civilian-deaths-riots-monthsLondonderry-violence.html.

Brown, W. (2000). Suffering rights as paradoxes. Constellations, 7, 230-241. doi:10.1111/1467-8675.00183.

Build-up to Moment Marine Shoots Dead [a] Wounded Taliban Fighter. (2017). [video]. London: Guardian, 2 February. Retrieved from https://www.theguardian.com/uknews/video/2017/feb/02/moment-marine-shoots-dead-wounded-taliban-fighter-video. Buckley, J. (2018a). MoD considers amnesty for soldiers who served in the Troubles amid fears of a 'witch-hunt' of ex-troops accused of decades-old allegations'. Daily Mail, 10 July. Retrieved from https://www.dailymail.co.uk/news/article-5936259/MoD-considersamnesty-soldiers-served-Troubles-amid-fears-witch-hunt.html.

Buckley, K. (2018b). Defence Secretary promises legal witch-hunt of Army veterans 'will end soon' as he proposes measures to stop those who fought in Northern Ireland and Iraq being dragged before judges'. Daily Mail, 4 December. Retrieved from https://www.dailymail.co.uk/news/article-6460843/Defence-Secretary-promises-legalwitch-hunt-Army-veterans-end-soon.html.

Burke, E. (2018). An Army of Tribes: British Army Cohesion, Deviancy and Murder in Northern Ireland. Liverpool: Liverpool University Press.

Burrell, I. (1999). Lord Denning, the century's greatest judge, dies at 100. Independent, 6 March. Retrieved from https://www.independent.co.uk/news/lord-denning-the-centurysgreatest-judge-dies-at-100-1078587.html.

Butler, J. (2010). Frames of War: When is Life Grievable? London: Verso.

Cadwallader, A. (2013). Lethal Allies: British Collusion in Ireland. Cork: Mercier Press.

Canny, N. (1973). The ideology of English colonization: from Ireland to America. The William and Mary Quarterly, 30, 575-98. doi:10.2307/1918596.

Carroll, R. (2018). 'Decades of deceit': Ballymurphy killings inquest opens in Belfast. The Guardian, 11 November. Retrieved from https://www.theguardian.com/uknews/2018/nov/11/decades-of-deceit-ballymurphy-killings-inquest-opens-in-belfast. Charters, D. (2017). Whose Mission, Whose Orders? British Civil-Military Command and Control in Northern Ireland, 1968-1974. Kingston, Ontario: McGill-Queen's University Press, 2017).

Clifford, M. (1916). It is 25 years since the Birmingham Six were released from prison'. Irish Examiner, 14 March. Retrieved from

https://www.irishexaminer.com/viewpoints/columnists/michael-clifford/it-is-25-yearssince-the-birmingham-six-were-released-from-prison-387162.html.

Colley, L. (2002). Captives: Britain, Empire and the World 1600-1850. London: Pimlico. Collins, T. Colonel. (2018). Legacy scandal: 'security forces must be protected from witchhunt to appease IRA', says Tim Collins. Belfast Newsletter, 20 August. Retrieved from https://www.newsletter.co.uk/news/opinion/legacy-scandal-security-forces-must-beprotected-from-witch-hunt-to-appease-ira-says-tim-collins-1-8607419. Committee on the Administration of Justice. (2015). The Apparatus of Impunity? Human Rights Violations and the Northern Ireland Conflict: A Narrative of Official Limitations on post-Agreement Investigative Mechanisms. Belfast: CAJ. Retrieved from 
https://caj.org.uk/2015/01/19/apparatus-impunity-human-rights-violations-northernireland-conflict/.

Committee on the Administration of Justice. (2013). Mapping the Rollback? Human Rights Provisions of the Belfast/Good Friday Agreement 15 Years On. Belfast: CAJ.

Committee on the Administration of Justice. (2011). Human Rights and Dealing with Historic Cases: A Review of the Office of the Police Ombudsman for Northern Ireland. Belfast: CAJ. Consultative Group on the Past. (2009). Report of the Consultative Group on the Past. London: HMSO. Retrieved from http://cain.ulst.ac.uk/victims/docs/consultative_group/cgp_230109_report.pdf. Cooper, N. and Hurcombe, M. (2009). The figure of the soldier. Journal of War and Cultural Studies. 2, 103-104. doi:10.1386/jwcs.2.2.103_2.

Dawson, G. (1994). Soldier Heroes: British Empire, Adventure and the Imagining of Masculinities. London: Routledge.

Deane, S. (1985). Civilians and Barbarians. Ireland's field day. London: Hutchinson, 33-44. De Baróid, C. (1989). Ballymurphy and the Irish War. Dublin: Aisling Publishers. Devlin, K. (2018). N Ireland veterans warn recruits over 'witch-hunt'. Sunday Express, 9 September. Retrieved from https://www.express.co.uk/news/uk/1015120/northernireland-veterans-the-troubles-witch-hunt-warning.

Drohan, B. (2017). Brutality in an Age of Human Rights: Activism and Counterinsurgency at the End of Empire. Ithaca NY: Cornell University Press.

Empire Warriors: Mad Mitch and His Tribal Law. (2004). [Documentary]. BBC. Retrieved from: https://www.dailymotion.com/video/x1vz96p.

Fallon, M. (2018). Allowing a one-sided witch hunt against British soldiers is a craven surrender to Sinn Fein. Telegraph, 9 May. Retrieved from https://www.telegraph.co.uk/politics/2018/05/09/allowing-one-sided-witch-hunt-againstbritish-soldiers-craven/.

Forsyth, F. (2017). Marine A: a shamble that shamed us. The Spectator, 30 March. Retrieved from https://blogs.spectator.co.uk/2017/03/marine-shambles-shamed-us/.

French, D. (2011). The British Way in Counterinsurgency, 1945-1967. Oxford: Oxford University Press.

Gilroy, P. (2004). After Empire: Melancholia or Convivial Culture. London: Routledge. Goffman, E. (1961). Asylums. New York NY: Doubleday.

Hawkes, S. and Johnson, J. (2016). 'End the witch hunt: Outrage as two former soldiers set to be prosecuted for allegedly murdering IRA man 44 years ago'. Sun, 16 December.

Retrieved from https://www.thesun.co.uk/news/2418066/outrage-as-two-former-soldiersprosecuted-for-allegedly-murdering-ira-man-44-years-ago/.

Hayner, P. (2010). Unspeakable Truths: Transitional Justice and the Challenge of Truth Commissions. Abingdon: Routledge, 2nd edn.

Hearty, K. (2014). The political and military value of the 'set-piece' killing tactic in East Tyrone, 1983-1992. State Crime, 3, 50-73. doi:10.13169/statecrime.3.1.0050.

Hickley, M. and Williams, D. (2007). 17 years after killing two joyriders, Lee Clegg is back on the frontline. Daily Mail, 11 September. Retrieved from

http://www.dailymail.co.uk/news/article-481284/17-years-killing-joyriders-Lee-Cleggline.html.

High Court of Justice of NI. (2011). McKeever V. MoD.

Hill, P.J. (1995). Forever Lost, Forever Gone. London: Bloomsbury. 
House of Commons Defence Committee. (2017). Investigations into Fatalities in Northern Ireland involving British Military Personnel: Seventh Report of Session 2016-2017, HC 1064, 26 April. Retrieved from

https://publications.parliament.uk/pa/cm201617/cmselect/cmdfence/1064/1064.pdf. Ignatieff, M. (2004). The Lesser Evil: Political Ethics in an Age of Terror. New York NY: Princeton University Press.

Ingham, J. (2018). Hundreds of Northern Ireland Troubles veterans to join demo at parliament. Daily Express, 6 June. Retrieved from

https://www.express.co.uk/news/uk/970049/northern-ireland-troubles-veterans-protesttreatment.

Jennings, A. (1990). Shoot to kill: The final court of justice. In A. Jennings (ed). Justice Under Fire: The Abuse of Civil Liberties in Northern Ireland. London: Pluto Press, $2^{\text {nd }}$ edn, 104-30. Kearney, V. (2018). PSNI chief disputes PM's “terrorists' claim. BBC News (Northern Ireland), 14 May. Retrieved from https://www.bbc.co.uk/news/uk-northern-ireland-44116267. Kearney, V. (2017). Troubles legacy cases bias disputed by figures. BBC News (Northern Ireland), 2 February. Retrieved from https://www.bbc.co.uk/news/uk-northern-ireland38844453

Attorney General Basil Kelly QC MP, in Committee on Interrogation Procedures: Minutes of the second 1972 meeting of the Committee, 17 January 1972.

Khalili, L. (2013). Time in the Shadows: Confinement in Counterinsurgencies. Stanford CA: Stanford University Press.

Lawther, C., Moffett, L. and Jacobs, D. (2016). Research Handbook on Transitional Justice. Cheltenham: Edward Elgar Publishing.

Leitch, W. (2018). Ballymurphy inquest: claims UVF sniper fired at civilians. BBC News, 13 November. Retrieved from https://www.bbc.co.uk/news/uk-northern-ireland-46196199. Marine ' $A$ ': The Inside Story. (2017). [documentary film]. London: BBC Panorama. Retrieved from: http://www.bbc.co.uk/iplayer/episode/b08hwmkg/panorama-marine-a-the-insidestory.

Little, A. (2018). Joint amnesty for IRA and Army veterans blocked'. Daily Express, 7 July. Retrieved from https://www.express.co.uk/news/uk/985213/ira-amnesty-veteran-gavinwilliams-slepped-down-by-downing-street.

Lundy, P. (2012). HET Briefing Paper: Research brief: Assessment of HET review processes and procedures in Royal Military Police investigation cases. Retrieved from https://cain.ulster.ac.uk/lundy/2012-04-02_Lundy_HET-Briefing-Paper.pdf. Lundy, P. (2008). Paradoxes and challenges of transitional justice at the 'local' level: historical enquiries in Northern Ireland. Contemporary Social Science, 6, 89-105. doi:10.1080/17450144.2010.534495.

Lundy, P. and McGovern, M. (2008). Truth, justice and dealing with the legacy of the past in Northern Ireland. Ethnopolitics, 7, 177-193. doi:10.1080/17449050701847319.

MacDonald, B. (2012). The 'Pitchfork' Murders: Uncovering the Cover-up. Fermanagh: Sinn Fein/An Phoblacht.

Marine 'A': Criminal or Casualty of War. (2015). [documentary film]. London: BBC Panorama. Retrieved from https://www.youtube.com/watch?v=il7bZpCWRC8.

Marine ' $A$ ': criminal or casualty of war. (2015). [documentary film]. London: BBC Panorama. Retrieved from https://www.youtube.com/watch?v=il7bZpCWRC8.

Matchett, W. (2018). Legacy scandal: 'Republican conspiracy nonsense has been indulged and the RUC trashed', says William Matchett. Belfast Newsletter, 21 August. Retrieved from 
https://www.newsletter.co.uk/news/opinion/legacy-scandal-republican-conspiracynonsense-has-been-indulged-and-the-ruc-trashed-says-william-matchett-1-8608457. Theresa May MP, Prime Minister, 'Prime Ministers Questions', Hansard, HC Deb, 9 May 2018, vol.640, cc.677. Retrieved from https://hansard.parliament.uk/Commons/2018-0509/debates/96F401BF-CC2F-4A7A-A208-1199480A6B9F/OralAnswersToQuestions. McAuslan, P. (2015). Property and empire: from colonialism to globalization and back. Social and Legal Studies, 24, 201-221. doi:10.1177/0964663915593010.

McCann, E. (2019). Bloody Sunday was a very British atrocity - the top brass got away with it. Guardian, 15 March. Retrieved from https://www.theguardian.com/commentisfree/2019/mar/15/bloody-sunday-derry-topbrass-one-soldier-charged.

McCann, E., Sheils, M. and Hannigan, B. (1992). Bloody Sunday in Derry: What Really Happened. Cork: Brandon.

McCartney, H. (2011). Hero, victim or villain? The public image of the British solider and its implications for defence policy'. Defence and Security Analysis, 27, 43-54.

doi:10.1080/14751798.2011.557213.

McDonald, H., Bowcott, O. and Mulholland, H. (2010). Bloody Sunday report: David Cameron apologises for 'unjustifiable' shootings. The Guardian, 15 June. Retrieved from https://www.theguardian.com/uk/2010/jun/15/bloody-sunday-report-saville-inquiry. McGarry, R. and Ferguson, N. (2012). Exploring representations of the soldier as victim: from Northern Ireland to Iraq. In Stephen Gibson and Simon Mollan (eds). Representations of Peace and Conflict. London: Palgrave Macmillan, 120-42.

McGarry, R. and Walklate, S. (2011). The soldier as victim: peering through the looking glass. British Journal of Criminology, 51, 900-17. doi:10.1093/bjc/azr057.

McGovern, M. (2019). Counterinsurgency and Collusion in Northern Ireland. London: Pluto Press.

McGovern, M. (2017). See no evil collusion in Northern Ireland. Race and Class, 58(3), 46-63. doi:10.1177/0306396816665565.

McGovern, M. (2016). Informers, agents and the liberal ideology of collusion in Northern Ireland. Critical Studies on Terrorism, 9, 292-311. doi:10.1080/17539153.2016.1175274. McGovern, M. (2015). State violence and the colonial roots of collusion. Race and Class, 57(2), 3-23. doi.org/10.1177/0306396815595200.

McGovern, M. (2013). Inquiring into Collusion? Collusion, the state and the management of truth recovery in Northern Ireland. State Crime, 2(1), 4-29.

doi.org/10.13169/statecrime.2.1.0004.

McGovern, M. (2010). Ignatieff, Ireland and the lesser evil. In B. Brecher, M. Devenney and A. Winter (eds). Discourses and Practices of Terrorism: Interrogating Terror. London: Routledge, 135-155.

McKittrick, D., Kelters, S., Feeney, S. and Thornton, C. (1999). Lost Lives: The Stories of the Men, Women and Children Who Died as a Result of the Northern Ireland Troubles.

Edinburgh: Mainstream Publishing.

'Memo from Head of C2 at HQNI and the Attorney General, 6 December 1971, AG 1971, pp.2-3'. Retrieved from https://www. patfinucanecentre.org/declassified-

documents/prosecution-british-soldiers.

Mendick, R. (2018). Prosecutors leave Bloody Sunday veterans in legal limbo. Telegraph, 18 November. Retrieved from https://www.telegraph.co.uk/news/2018/11/18/prosecutorsleave-bloody-sunday-veterans-legal-limbo/. 
Moloney, C. (2018). 'End the witch hunt': Special forces veterans unite against May amid plans for $£ 150 m$ probe. Daily Express, 25 August. Retrieved from https://www.express.co.uk/news/politics/1008358/sas-veterans-troubles-northern-irelandtheresa-may-latest.

Mosse, G. (1990). Fallen Soldiers: Reshaping the Memory of the World Wars. Oxford: Oxford University Press.

Mullan, D. (1997). Bloody Sunday: Massacre in Northern Ireland: The Eyewitness Accounts. Niwot, CO: Robert Rhinehart Publishers.

Mullin, C. (1990). Error of Judgement: The Truth About the Birmingham Bombings. Dublin: Pollbeg, 2nd edn.

Murray, R. (1990). The SAS in Ireland. Mercier Press: Cork.

Newsinger, J. (2002). British Counter-Insurgency from Palestine to Northern Ireland. Basingstoke: Palgrave.

Newton Dunn, T. and Wilkinson, M. (2017, March 31). Bloody outrage: decision to investigate brave British soldiers over all the killings in Northern Ireland's 30 years of The Troubles branded "witch hunt". Sun. Retrieved from https://www.thesun.co.uk/news/2353150/decision-to-investigate-brave-british-troopsover-killings-in-northern-irelands-30-years-of-the-troubles-branded-witch-hunt/. Ní Aoláin, F. (2000). The Politics of Force: Conflict Management and State Violence in Northern Ireland. Belfast: Blackstaff Press.

Northern Ireland Office (NIO). (2018). Consultation Paper: Addressing the Legacy of Northern Ireland's Past. Belfast: NIO. Retrieved from

https://assets.publishing.service.gov.uk/government/uploads/system/uploads/attachment data/file/709091/Consultation_Paper_Addressing_the_Legacy_of_Northern_Irelands_Past. pdf.

Northern Ireland Office (NIO). (2014). The Stormont House Agreement. Belfast: NIO.

Retrieved from

https://www.gov.uk/government/uploads/system/uploads/attachment_data/file/390672/S tormont_House_Agreement.pdf.

Obituary: Lt-Col C. C. 'Mad Mitch' Mitchell. (1996). Telegraph, 24 July. Retrieved from http://www.telegraph.co.uk/news/obituaries/military-obituaries/armyobituaries/5796166/Lt-Col-C-C-Mad-Mitch-Mitchell.html.

Orr, D.A. (2003). From a view to a discovery: Edmund Spenser, Sir John Davies and the defects of law in the realm of Ireland. Canadian Journal of History, 38, 395-408.

doi:10.3138/cjh.38.3.395.

Orwell, G. (1982). The Lion and the Unicorn: Socialism and the English Genius. London: Penguin, 4th edn.

O'Toole, F. (2018). Heroic Failure: Brexit and the Politics of Pain. London: Apollo.

O'Toole, F. (2016). Brexit is being driven by English nationalism. And it will end in self-rule. Guardian. 19 June. Retrieved from https://www.theguardian.com/commentisfree/2016/jun/18/england-eu-referendumbrexit.

Owens, P. (2015). Economy of Force: Counterinsurgency and the Historical Rise of the Social. Cambridge: Cambridge University Press.

Pat Finucane Centre. (2014). The Hidden History of the UDR: The Secret Files Revealed. Derry: Pat Finucane Centre. 
Pawlisch, H.S. (2010). Sir John Davies and the Conquest of Ireland: A Study in Legal Imperialism. Cambridge: Cambridge University Press, $2^{\text {nd }}$ edn.

Prime Minster Theresa May MP, 'Prime Minister Questions', Hansard, HC Deb, 12 September 2018, vol.646, cc.754.

Punch, M. (2012). State Violence, Collusion and the Troubles: Counter Insurgency, Government Deviance and Northern Ireland. London: Pluto Press.

Rayment, S. (2005). 15 years after killing joyrider, Lee Clegg is put back in the line' Telegraph, 23 October. Retrieved from

http://www.telegraph.co.uk/news/worldnews/middleeast/iraq/1501255/15-years-afterkilling-joyrider-Lee-Clegg-is-put-back-in-the-line.html.

Rolston, B. (2005). 'An effective mask for terror': democracy, death squads and Northern Ireland'. Crime, Law and Social Change, 44, 181-203. doi:10.1007/s10611-006-9007-7.

Ryder, C. (1991). The Ulster Defence Regiment: An Instrument of Peace? London: Methuen. Sanders, A. (2013). Operation Motorman (1972) and the search for a coherent British counterinsurgency strategy in Northern Ireland, Small Wars and Insurgencies, 24, 465-492. doi.org/10.1080/09592318.2013.802609.

Saville, M., Hoyt, W. and Toohey, J. (2010). Report of the Bloody Sunday Inquiry: Volume 1. HC29 2010-11. London: HMSO.

Saville, M. Lord. (2010). Report of the Bloody Sunday Inquiry. London: TSO. Retrieved from https://www.gov.uk/government/publications/report-of-the-bloody-sunday-inquiry. Scruton, R. (2017). Where We Are: The State of Britain Now. London: Bloomsbury. Scruton, R. (2014). The Need for Nations. Public lecture delivered, Budapest, Hungary. Retrieved from https://www.roger-scruton.com/articles/276-the-need-for-nations. Scruton, R. (2001). England: An Elegy. London: Pimlico.

Sedley, S. (1999). 'A Benchmark of British Justice'. The Guardian, 6 March. Retreived from https://www.theguardian.com/news/1999/mar/06/guardianobituaries.

Stewart, S. (2017). Military vets group backs far right foot bams and claim thug leader 'demonised'. Daily Record, 4 November. Retrieved from

https://www.dailyrecord.co.uk/news/scottish-news/military-vets-group-back-far-11464071. Tharoor, S. (2017). Inglorious Empire: What the British did to India. London: C. Hurst \& Co. Thompson, E.P. (1975). Whigs and Hunters: The Origins of the Black Act. London: Allen Lane. Thompson, E.P. (1965). The peculiarities of the English. Socialist Register, 311-362.

The Ballymurphy Precedent. (2018) [documentary film] London: Channel 4.

Urban, M. (1997). UK Eyes Alpha: The Inside Story of British Intelligence. London: Faber and Faber $2^{\text {nd }}$ edn.

Urban, M. (1992). Big Boys' Rules: The Secret Struggle Against the IRA. London: Faber and Faber.

Veterans against Terrorism [website]. Retrieved from

https://veteransagainstterrorism.blog/.

Walker, S. Victims' Commissioner says PM's facts 'incorrect'. (2018). BBC News (Northern Ireland), 14 May. Retrieved from https://www.bbc.co.uk/news/uk-northern-ireland44088827.

Walsh, D. (2000). Bloody Sunday and the Rule of Law in Northern Ireland. Dublin: Gill and Macmillan.

Widgery, J. Lord. (1972). Report of the Tribunal appointed to inquire into the events on Sunday, 30 January 1972, which led to loss of life in connection with the procession in 
Londonderry on that day. London: HMSO. Retrieved from

https://cain.ulster.ac.uk/hmso/widgery.htm.

Willetts, D. (2018). End the vendetta: MPs sign damning letter to Theresa May pleading with her to end legal witch-hunt of army veterans. Sun, 27 June. Retrieved from https://www.thesun.co.uk/news/6634674/mps-end-witchhunt-of-army-veterans/. Wittman, L. 2011. The Tomb of the Unknown Soldier: Modern Mourning and the Reinvention of the Mystical Body. Toronto: University of Toronto Press.

Wood, E. M. (2003). Empire of Capital. London: Verso.

Young, D. (2017). 'No bias displayed' in decision to prosecute British soldiers. Irish News, 30 January 2017. Retrieved from

https://www.irishnews.com/news/northernirelandnews/2017/01/30/news/-no-bias-

displayed-in-decision-to-prosecute-british-soldiers-912523/.

Mark McGovern is Professor in Sociology at Edge Hill University, UK. His research on state violence and conflict transformation in Northern Ireland has involved close collaboration over many years with NGOs, victims' groups and lawyers. He is the author of Counterinsurgency and collusion in Northern Ireland (Pluto, 2019).

\footnotetext{
'The PSNI replaced the Royal Ulster Constabulary (RUC) as the police force for Northern Ireland following sweeping reforms introduced as part of the post-Good Friday Agreement settlement.

ii The House of Commons Committee also recommended such an amnesty should be extended to former members of the RUC.

iii Civilians and Barbarians was originally published as a pamphlet in 1983.

iv There have been recent, at present unsubstantiated, claims that two members of a loyalist paramilitary organisation, the Ulster Volunteer Force (a pro-state, Protestant paramilitary group) were also firing at Catholic civilians in Ballymurphy at the time of the massacre from a nearby Protestant estate. See, for example, Leitch, 2018.

${ }^{\vee}$ The father of thirteen was Danny Teggart, the mother of seven was Joan Connolly and the Catholic priest (shot dead while going to the aid of Bobby Clarke, himself wounded from a shot in the back) was Fr Hugh Mullan. The other victims were Joseph Corr, Eddie Doherty, John Lavery, Paddy McCarthy, John McKerr, Joseph Murphy, Noel Phillips and Frank Quinn. See, ballymurphymassacre.com/cms/the-victims.

${ }^{v i}$ The victim was 20-year-old Noel Phillips. See, ballymurphymassacre.com/cms/noel-phillips.

vii The eleventh victim was Paddy McCarthy. He was stopped by an Army patrol on 11 August and had a gun thrust into his mouth. He suffered the heart attack shortly after.
} 